\title{
Evaluation of Some Private Commercial Banks in Bangladesh from Performance Perspectives
}

\author{
Md Reaz Uddin ${ }^{1}$, Jannatul Ferdous Bristy ${ }^{2}$ \\ ${ }^{1}$ Assistant Professor, Business Administration Discipline, Khulna University, Khulna - \\ 9208, Bangladesh \\ ${ }^{2}$ Independent Researcher, Khulna -9208, Bangladesh
}

\begin{abstract}
Banks operate on a huge scale at the heart of the modern economy and the banking system has become an integral part in the progress of economic development in Bangladesh. Besides, the banking sector has made their innovation and efficiency crucial to the economy as it competes in an e-commerce world. The role of banking system in this situation cannot be denied at all. This report intends to evaluate the performance of selected private commercial banks in Bangladesh. In the study, best efforts have been put on evaluating the performance. The growing pattern of branches, employees, deposits, loans and advances, classified loan, net income and earnings per share of selected private commercial banks has been considered to make an analysis on the performance evaluation of the selected private commercial banks. To evaluate the performance, data have been collected from the secondary sources. Then the collected data have been analyzed. From the analysis, it has been found that all of the selected banks are in a position to make a sustainable growth in respect of branches, employees, deposits, loans and advances, classified loan, net income and earnings per share during the period of 2007-2011 with some fluctuation. Besides the growth pattern, other forms of calculations have been used for every selected variable and they are trend equation and square of correlation coefficient. Under trend equation analysis, the variables named branches, employees, deposits and net incomes hold more positive value than the other variables considered. As the value of the slope always shows the positive number, it is a clear indication that Bangladesh has a very good prospect in case of private commercial banks.
\end{abstract}

\section{Key words:}

Performance Evaluation, Commercial Banks, Earning per Share, Net Income

\section{INTRODUCTION:}

Banking system has become an integral part for operating economic activities in every country. The economic condition of a country depends on the soundness of its banking system (Teker, et al. 2011). A bank in a country is so important that the economy of a country may come to a standstill without these banking activities. Just as without heart the existence of any human being can't be thought, economic activities without the help of banking system is unthinkable (Stankeviciene and Mencaite, 2012). By giving financial support during business startups, providing loans to smooth and increase the level of production,controlling the supply of money in circulation, supporting modern trade and commerce, keeping people's money safe,affecting spending and saving tendencies, providing capital for innovation and infrastructure, facilitating foreign trades and so on, banking sector is actually fueling the engine of development of a country. Thus any disturbance to this banking sector will surely have a severe impact on the country's economic growth(Aspal and Malhotra, 2013).

Banking industry is one of the most vibrant and growing industry of Bangladesh. Today there are fifty-six scheduled banks in this country. Growth of this industry can be traced back to its 
starting with six nationalized commercialized banks, two state owned specialized banks and three foreign banks after the independence of Bangladesh in 1971. Central bank of Bangladesh is named as "Bangladesh Bank". All the other banks in this country operate under full control and supervision of this Bangladesh Bank under Bangladesh Bank Order, 1972 and Bank Company Act, 1991 (Amended in 2003). With the entrance of private banks, banking industry of Bangladesh experienced a significant growth during 1980's. Banks in Bangladesh are broadly classified as scheduled and non-scheduled banks. Scheduled banks are again of different types, like: State Owned Commercial Banks (SOCBs), Specialized Banks (SDBs), Private Commercial Banks (PCBs) including Conventional PCBs and IslamiShariah based PCBs and Foreign Commercial Banks (FCBs). At present there are four SOCBs, four SDBs, thirty-nine PCBs where thirty-one are conventional and eight IslamiShariahbased, nine FCBs and four nonscheduled banks. Recently, the number of banks and most importantly their branches are increasing at a tremendous rate (Bangladesh Bank, 2014).

With this increase of competition in banking industry, every bank is trying to provide their customers better services as much as possible to ensure maximum satisfaction (Uppal, 2010). As bank is basically a service based business, performance for every bank depends on the service quality they are providing for their customers. Evaluation of bank's performance from time to time helps them to know how well they are actually satisfying their customers and becoming successful. The performance evaluation of banks has thus taken high priority in the context of Bangladesh (Siddique\& Islam, 2001). If efficiency is gained in the banking sector, it will make the country domestically and internationally more competitive and capable of generating more income and employment opportunities. An appropriate evaluation of performance of selected banks requires a range of financial, operational and economic indicators to be applied (Chowdhury, 2002). Evaluation of performance measures the rate of growth in the banking system. This study has been conducted to execute the performance evaluation of some selected private commercial banks of Bangladesh. It will help the respective banks to improve their weaker areas and also help the shareholders to make informed decisions based on the bank's financial prospects.

\section{LITERATURE REVIEW:}

Determining how well an organization is doing is simply its performance evaluation. In other words, setting some standards for performance measurement, comparing the performance of an organization in a certain period of time with respect to some established standards- internal or industry wise and determining how well it has confirmed to those standards along with the reasons for that performance is broadly called performance evaluation. A well guided performance evaluation can bring out the strengths and weaknesses of the organization and it also provides a guideline for future improvements. For being the performance evaluation system efficient, it must cover all aspects of the organization(Almazari, 2011).

Performance evaluation is one of the important issues for any bank especially for private commercial banks because a link exists between performance and profit earning. It also helps a bank to determine how well it is performing in compare to others. Performance evaluation is needed for a bank to position itself in a way to see what are needed to add, remove or change to improve the current condition. Simply how well the bank is using its resources to earn profit it indicated by its performance evaluation (Bingham and Houston, 2004).

Banking industry is now one of the mostly competitive and fastest growing services based industry throughout the globe. In Bangladesh, it is also equally true. Considering the overall development of the country, the government has converted some state-owned firms into privately-owned firms through public share offering. They offer share issue for privatization at a 
low price, make an allocation of the share to selectfavoured domestic investors, have controlling restrictions on privately owned firm and typically use fixed price offer rather than competitive tender offer. It is also said that private ownership is preferable to public ownership because it fosters competition and reduces political patronage and corruption (Hossain and Bhuiyan, 1990 \&Shleifer, 1998).

Moreover, the services of private commercial banks in this country are now better than before. As a result, the clients are rushing to the private banks. Consequently, the private commercial banks are constantly growing in different branches, creating employment opportunities, increasing deposit, loan disbursement, net income and earnings per share over a period of time. As competition is rising in the banking industry due to the emergence of new banks in the market, it has become important to evaluate the performance of every private commercial bank (Chowdhury and Islam, 2009).

Most common indicator of performance of any organization is its profitability. Higher profitability indicates better performance whereas lower profitability indicates poor performance (Bhatt and Ghosh, 1992). But the measurement of bank's profitability is quite different from any other sector of business because it is only bank which works with loan and deposit. The loan-todeposit ratio works as a very good indicator of banks' profitability as it depicts the status of asset liability management of banks (Jahangir et al. 2007). Using ratio system is another way for evaluating the performance of a firm like bank. In this system, present ratio is compared with the past ratio. It provides an indicator of the direction of change and shows whether the firm's financial performance has developed, deteriorated or remained constant over time (Pandy, 2006).

Like other businesses bank is also evaluated in perspective of future profit and loss potential which is one of the key indicators. The bank is said to be successful when the shareholders of the bank get more profit than the bank. If relevant risks are effectively controlled, banks can attain success. It requires the professional use of bank's assets anon-professional maintenance of assets of any sort of bank is regarded as the main cause for loan default problem (Alam and Jahan, 1999). As profit earning is the main target of any private commercial bank, it's earning capacity shows how much capable the bank is to earn profit. This earning capacity can be measured by profitability ratio. Among profitability ratios, return on equity (ROE) is one of the most popular indicators of earning capacity. It is also suggested by the return on equity ratio that the higher the return on equity a company will show; the more capable it is to earn profit (Horne and Wachowicz, 2005 \&Al-Shamrnari and Salimi, 1998).

To measure the performance of banks, several models are available. One of the models is the predictive model which works with dependent and independent variables. Such type of model allows a comparison between the predicted and actual levels of key business drivers and thus it measures unrealized performance (Avkiran, 1997). In measuring performance level of a bank, some variables like employee, deposits, loan and advances, profits etc. are used. These variables help the selected bank to evaluate the overall performance of the bank. The increasing number of employees, larger amount of deposit, more loan disbursement, and higher profitability indicate that the bank is performing well and in some cases better than before (Swampy and Vasudevan, 1985).

In the literature of bank performance, numerous scholars have made significant contributions. They have developed and used different models to measure the current performance of banks and also the future prospects. 
Alkhatib and Harsheh (2012) examined the financial performance of five Palestinian commercial banks using three indicators: Internal-based, Market-based and Economic-based performance measures. Return on Assets, Tobin's Q model and Economic Value add methods have been used for measuring these three indicators. Correlation and multiple regression analysis have been applied in this study to analyze the influence of bank size, credit risk, operational efficiency and asset management on financial performance and to create a good-fit regression model to predict the future financial performance of these banks. As findings, the study has indicated that there is a significant impact of bank size, credit risk, operational efficiency and asset management on financial performance of Palestinian commercial banks.

Sangmi and Nazir (2010) evaluated the financial performance of the two major northern Indian banks using CAMEL Parameters. In this study the positions of these two banks have been highlighted as sound and satisfactory with respect to their capital adequacy, asset quality, management capability and liquidity.

Within the context of Bangladesh, Roy and Khan (2013) investigated the effect of overall service quality, product quality, and corporate social performance on reputation of private commercial banks. After the survey of eighty clients and employees of ten private commercial banks of Dhaka City area, the study applied correlation and stepwise regression to assess the hypothesis. The correlation analysis supported the entirehypotheses but the stepwise regression provided partial support. However, the study concluded that overall service quality, overall product quality, and corporate social performance are statistically and significantly correlated with bank reputation.

Karim and Alam (2013) intended to measure the performance of five selected private banks. Financial ratios indicating the adequacy of the risk based capital, credit growth, credit concentration, non-performing loan position, liquidity gap analysis, liquidity ratio, return on assets (ROA), return on equity (ROE), net interest margin (NIM), etc. have been used. Internalbased, Market-based and Economic-based performance indicators have been measured by Return on Assets, Tobin's Q model and Economic Value add. Employing multiple regression analysis they also attempted to apprehend the impact of bank size, credit risk, operational efficiency and asset management on financial performance and found that the impact is significant. It has also created a good-fit regression model to predict the future financial performance of the selected banks.

Using secondary data for a period of 2005 to 2009 Almazari (2011) attempted to evaluate the financial performance of seven selected Jordanian commercial banks. The financial performance has been studied using financial variables and ratios and it found that higher total deposits, credits, assets, and shareholders' equity of banks do not always infer better profitability or performance. Besides, simple regression has been applied to estimate the impact of bank size, asset management, and operational efficiency on financial performance (return on assets and interest income size) and the result showed a highly positive correlation.

For the period 2003-2004, Kosmidou and Zopounidis (2008) evaluated and rated the performance and efficiency of the commercial and cooperative banks in Greece. They found in this study that commercial banks are becoming more competitive and maximizing their profits by increasing their accounts, attracting more customers and improving their financial indices. But in case of the cooperative banks, it has been found that, some are enjoying considerably increased profits and market shares while financial indices have been found to be deteriorating for others. 
After the East Asian financial crisis, Chantapong (2005) examined the performance in terms of profitability and other characteristics of domestic and foreign banks of Thailand. The paper studied cross-bank time-series data and important financial ratios from balance sheets and income statements of these banks for a period of 1995-2000. It was found that though all banks reduced their credit exposure during the crisis they gradually improved their profitability during the post-crisis period. The study also found foreign bank profitability to be higher than the average profitability of the domestic banks. However, it also found that this gap is becoming closer due to the financial restructuring program.

Hirtle and Stiroh (2007) studied the impact of U.S. banks' retail intensity on performance from 1997 to 2004. Retail intensity was measured in terms of loan share, deposit share, and branches per dollar of assets. The paper compared these measures with both equity market and accounting measures of performance. The results indicated that retail banking yields low yet stable return. The conclusion was derived from the findings that retail banking activity of US banks were linked with significantly lower equity market but it lowered volatility for only the largest banks.

Stankeviciene and Mencaite (2012) attempted to evaluate the usefulness of a multicriteria decision making approach, particularly the Analytical Hierarchy Process (AHP) model to evaluate the performance of Lithuanian banks. The model which is based on a system of various qualitative and quantitative criteria and their mutual relations creates and describes a system of indicators. Then taking into account the needs and priorities of both internal and external evaluators each indicator is assigned a different degree of significance. Using this AHP model, authors have been able to compare banks of Lithuanian market between each other. Ranking of these banks were also identified and the banks that are taking leading positions were also indicated. Finally the study concluded that the AHP model is appropriate to for evaluating bank performance.

Ho and Zhu (2004) evaluated the performance of forty-one banks in Taiwan separating efficiency and effectiveness of performance using an innovative two-stage data envelopment analysis model. From the analysis the authors concluded that better efficiency does not always mean better effectiveness as they didn't find any apparent correlation between these two indicators.

In theirpaper,Aspal and Malhotra (2013) attempted to evaluate the financial performance of Indian public sector banks for the period of 2007-11 where they excluded State Bank Group. They found that due to better performance in the areas of liquidity and asset quality, Bank of Baroda was at the first position. Andhra Bank closely followed Bank of Baroda being at the second position with its strength in management efficiency, capital adequacy and asset quality. Whereas, due to management inefficiency, poor assets and earning quality, the authors found United Bank of India to hold the bottom most rank.

Developing and using an indexing model Teker et al. (2011) evaluated financial performances of commercial banks of Turkey for the period of 2003 - 2010. In the model fundamental performance characteristics of banks were considered and related explanatory factors determining these characteristics were chosen. In this study, 13 commercial banks of were ranked by employing the proposed indexing model for each of the years. In addition to that, a comparison of the results of proposed performance measurement system to annual net income and ROE of banks was made.

Employing financial ratios to measure the profitability, liquidity and credit quality performance of five large South African based commercial banks for the period of 2005- 2009, Kumbirai\& Webb (2010) found that though overall bank performance increased considerably in the first two 
years of the analysis, there was a significant change in trend at the time of the global financial crisis in 2007. This trend reached its peak during 2008-2009 and resulted in falling profitability, low liquidity and deteriorating credit quality in the South African Banking sector.

From the above discussion, some factors can be taken as the indicator of performance evaluation of private commercial banks. These are the growth rate, earning per share, profitability rate, increase or decrease of fixed assets, assessment of net income, sector enhancement, accumulation of greater deposit, smooth loan recovery etc. To conduct this research, some variables have been identified to measure. These are Number of Branches, Employees, Deposit, Loan and Advances, Classified Loan, Net Income and EarningsperShare. These variables will help to measure the performance of the selected private commercial banks in this study.

\section{OBJECTIVES:}

- To evaluate the performance of selected private commercial banks in Bangladesh

- To evaluate the analysis of commercial banks in Bangladesh

\section{METHODOLOGY:}

As the report focuses on the performance evaluation of private commercial banks in Bangladesh, at first some private commercial banks in Bangladesh have been selected. The banks are Brac Bank, City bank, Eastern Bank, IFIC Bank, Mercantile Bank. Since the report is based on secondary sources, some secondary sources like internet, Stock Exchange, annual reports of the selected private commercial banks have been used to accumulate the data. Five years' (20072011) information has been analyzed in the research. On the basis of the information collected, an analysis has been made. To make the analysis, two methods have been applied and they are straight-line trend method and the square of correlation coefficient.

The straight-line trend method represents the equation $Y_{c}=a+b x$. In this equation, $Y_{c}$ denotes the trend values to distinguish them from the actual $Y$ value. "a" represents $Y$ intercept. " $b$ " is the slope of the line of the amount of change in $\mathrm{Y}$ variable that is associated with a change of one unit in $x$ variable. " $x$ " variable in the time series analysis represents time. The square of correlation coefficient is represented by $r^{2}$. The value of $r$ does not exceed 1 rather it lies between 0 and 1 . If the value of $r^{2}$ is higher, it indicates that the percentage of the variation of $Y$ gets larger (Gupta and Gupta, 2003 \&Malhotra and Dash, 2011). SPSS 16.0 and Microsoft Excel have been used to make the analysis. After the analysis and interpretation, some findings have been found and those findings result in some conclusion.

\section{ANALYSIS AND INTERPRETATION:}

At the very beginning of the analysis here are the year wise absolute data and the growth rate of selected variables: number of branches, number of employees, deposit, loan and advances, classified loan, net income and earnings per share. Then the trend equations and the correlation coefficients are presented.

\subsection{Number of Branches:}

Table 1 reveals that the number of branches is increasing in course of time. In case of Brac Bank, the number of branches is growing at a decreasing rate. That is, the percentage growth rate is decreasing. The number of branches of City Bank is increasing at a lower rate than any other 
International Journal of Managing Value and Supply Chains (IJMVSC) Vol. 5, No. 4, December 2014

selected bank. To say regarding Eastern Bank, the number of branches is increasing but the percentage of growth rate fluctuates.

Table 1: Number of Branches of Selected Private Commercial Banks

\begin{tabular}{|c|c|c|c|c|c|c|}
\hline SL & Name of Banks & \multicolumn{5}{|c|}{ Number of Branches } \\
\hline & & 2007 & 2008 & 2009 & 2010 & 2011 \\
\hline 1 & Brac Bank Ltd. & 36 & 56 & 70 & 79 & 81 \\
\hline & Growth & & $55.56 \%$ & $25 \%$ & $12.86 \%$ & $2.53 \%$ \\
\hline 2 & City Bank Ltd. & 83 & 83 & 87 & 88 & 89 \\
\hline & Growth & & $00 \%$ & $4.82 \%$ & $1.15 \%$ & $1.14 \%$ \\
\hline 3 & $\begin{array}{c}\text { Eastern Bank } \\
\text { Ltd. }\end{array}$ & 28 & 34 & 39 & 49 & 59 \\
\hline & Growth & & $21.43 \%$ & $14.71 \%$ & $25.64 \%$ & $20.41 \%$ \\
\hline 4 & IFIC Bank Ltd. & 69 & 74 & 82 & 95 & 99 \\
\hline & Growth & & $7.25 \%$ & $10.81 \%$ & $15.85 \%$ & $4.21 \%$ \\
\hline 5 & $\begin{array}{c}\text { Mercantile Bank } \\
\text { Ltd. }\end{array}$ & 41 & 42 & 53 & 65 & 75 \\
\hline & Growth & & $2.44 \%$ & $26.19 \%$ & $22.64 \%$ & $15.38 \%$ \\
\hline
\end{tabular}

Sources: Annual reports of Brac Bank, City Bank, Eastern Bank, IFIC Bank and Mercantile Bank (2007-2011).

In case of IFIC Bank, at the beginning the branches were increasing at an increasing rate but in 2011 the number of branches has increased at a decreasing rate. Mercantile Bank has maintained a good growing number of branches. Because among all the banks, the difference between the percentage growth rates of the years except 2008 is lower than any other bank mentioned above in the table.

Table 2: Trend equation and $\mathrm{r}^{2}$ of Branches

\begin{tabular}{|c|c|c|c|}
\hline SL & Bank & $\mathrm{Y}_{\mathrm{c}}=\mathrm{a}+\mathrm{bx}$ & $\mathrm{r}^{2}$ \\
\hline 1 & Brac Bank Ltd. & $64.4+11.3 \mathrm{x}$ & .91 \\
\hline 2 & City Bank Ltd. & $86+1.7 \mathrm{x}$ & .90 \\
\hline 3 & Eastern Bank Ltd. & $41.8+7.7 \mathrm{x}$ & .98 \\
\hline 4 & IFIC Bank Ltd. & $83.8+8.1 \mathrm{x}$ & .97 \\
\hline 5 & Mercantile Bank Ltd. & $55.2+9.1 \mathrm{x}$ & .95 \\
\hline
\end{tabular}


Sources: Annual reports of Brac Bank, City Bank, Eastern Bank, IFIC Bank and Mercantile Bank (2007-2011).

Now table 2 above shows the trend equation and square of correlation coefficient $\left(\mathrm{r}^{2}\right)$ of branches of every selected private commercial bank. The analysis shown on the table provides positive trend equation for every selected bank. Again square of correlation coefficient is also high for the banks selected. Among all the banks, Eastern Bank shows the highest square of correlation coefficient i.e. .98.

\subsection{Number of Employees:}

Table 3 indicates the number of employees and growth rate of employees of the selected private commercial banks. Brac Bank has the highest number of the employees in 2007 and in 2011 it also belongs to the highest number of employees. From 2007 to 2008, the number of employees has decreased but after that the number has increased for the two consecutive years. Though the number of employees has decreased in 2011, this bank has the highest number of employees among all of the five banks. The growth percentage rate is higher in Mercantile Bank and lower in IFIC Bank.

Table 3: Employees of Selected Private Commercial Banks

\begin{tabular}{|c|c|c|c|c|c|c|}
\hline SL & Name of Banks & \multicolumn{5}{|c|}{ Number of Employees } \\
\hline & & 2007 & 2008 & 2009 & 2010 & 2011 \\
\hline 1 & Brac Bank Ltd. & 4428 & 4192 & 5907 & 7151 & 6619 \\
\hline & Growth & & $-5.33 \%$ & $40.82 \%$ & $21.14 \%$ & $-7.44 \%$ \\
\hline 2 & City Bank Ltd. & 1991 & 2134 & 2424 & 2685 & 2772 \\
\hline & Growth & & $7.18 \%$ & $13.59 \%$ & $10.77 \%$ & $3.24 \%$ \\
\hline 3 & Eastern Bank Ltd. & 690 & 763 & 878 & 973 & 1214 \\
\hline & Growth & & $10.58 \%$ & $15.07 \%$ & $10.82 \%$ & $24.77 \%$ \\
\hline 4 & IFIC Bank Ltd. & 1997 & 2110 & 2193 & 2315 & 2383 \\
\hline 5 & $\begin{array}{c}\text { Growth } \\
\text { Mercantile Bank }\end{array}$ & 945 & 1115 & 1300 & 1605 & 1826 \\
\hline & Ltd. & & $12.06 \%$ & $16.59 \%$ & $23.46 \%$ & $13.77 \%$ \\
\hline
\end{tabular}

Sources: Annual reports of Brac Bank, City Bank, Eastern Bank, IFIC Bank and Mercantile Bank (2007-2011)

In table 4, the summary of trend equation and $r^{2}$ of Employee expansion of selected private commercial banks has been shown and it tells us that every selected bank has very positive trend equation. It also reflects that the goodness of fit of all the equations is high. It is more than $90 \%$ for all selected banks except Brac Bank. For Brac Bank it is .78. Among all the selected banks, IFIC Bank holds the best fit because its $\left(r^{2}\right)$ is .99 . 
International Journal of Managing Value and Supply Chains (IJMVSC) Vol. 5, No. 4, December 2014

Table 4: Trend equation and $\mathrm{r}^{2}$ of no. of Employees

\begin{tabular}{|c|c|c|c|}
\hline SL & Bank & $\mathrm{Y}_{\mathrm{c}}=\mathrm{a}+\mathrm{bx}$ & $\mathrm{r}^{2}$ \\
\hline 1 & Brac Bank Ltd. & $5658.6+734.1 \mathrm{x}$ & .78 \\
\hline 2 & City Bank Ltd. & $2401.2+211.3 \mathrm{x}$ & .97 \\
\hline 3 & Eastern Bank Ltd. & $903.6+125.8 \mathrm{x}$ & .95 \\
\hline 4 & IFIC Bank Ltd. & $2199.6+97.7 \mathrm{x}$ & .99 \\
\hline 5 & $\begin{array}{c}\text { Mercantile Bank } \\
\text { Ltd. }\end{array}$ & $1368.2+215.2 \mathrm{x}$ & .98 \\
\hline
\end{tabular}

Sources: Annual reports of Brac Bank, City Bank, Eastern Bank, IFIC Bank and Mercantile Bank (2007-2011).

\subsection{Number of Deposits:}

It is shown from the table 5 that the deposit is highest in City Bank and it is 40540 million and lowest in IFIC Bank and the amount is 36092 million. But in 2008 the deposit has become higher for Brac Bank and also the percentage of growing rate is higher for Brac Bank. From 2007 to 2011, all the banks are showing that the deposit has grown more than every previous year. In 2011, the highest deposit belongs to Brac Bank and the amount is 103726 million and the lowest deposit belongs to IFIC Bank and its amount is 73106 million.

Table 5: Deposits of Selected Private Commercial Banks (in millions)

\begin{tabular}{|c|c|c|c|c|c|c|}
\hline SL & Name of Banks & \multicolumn{5}{|c|}{ Number of Deposit } \\
\hline & & 2007 & 2008 & 2009 & 2010 & 2011 \\
\hline 1 & Brac Bank Ltd. & 37368 & 58007 & 75220 & 85158 & 103726 \\
\hline & Growth & & $55.23 \%$ & $29.67 \%$ & $17.2 \%$ & $17.66 \%$ \\
\hline 2 & City Bank Ltd. & 40540 & 45064 & 62384 & 67420 & 83818 \\
\hline & Growth & & $11.16 \%$ & $38.43 \%$ & $8.07 \%$ & $24.32 \%$ \\
\hline 3 & Eastern Bank Ltd. & 30092 & 41573 & 49190 & 56425 & 75536 \\
\hline 4 & Growth & & $38.15 \%$ & $18.32 \%$ & $14.71 \%$ & $33.87 \%$ \\
\hline & IFIC Bank Ltd. & 29900 & 36092 & 50018 & 54660 & 73106 \\
\hline 5 & Mrowth & & $20.71 \%$ & $38.58 \%$ & $9.28 \%$ & $33.75 \%$ \\
\hline & Growth & & $25.78 \%$ & $17.15 \%$ & $30.32 \%$ & $35.22 \%$ \\
\hline
\end{tabular}


Sources: Annual reports of Brac Bank, City Bank, Eastern Bank, IFIC Bank and Mercantile Bank (2007-2011).

It has been found from table 6 that every selected bank has positive trend equation and square of correlation coefficient is extremely high in case of deposit accumulation. Among all the banks Brac Bank has higher value for trend equation than any other selected private commercial bank. The square of coefficient correlation is more than $90 \%$ for every bank analyzed. Among those, again Brac bank holds the highest goodness of fit.

Table 6: Trend equation and $\mathrm{r}^{2}$ of Deposit

\begin{tabular}{|c|c|c|c|}
\hline SL & Bank & $\mathrm{Y}_{\mathrm{c}}=\mathrm{a}+\mathrm{bx}$ & $\mathrm{r}^{2}$ \\
\hline 1 & Brac Bank Ltd. & $72495.8+16286.7 \mathrm{x}$ & .99 \\
\hline 2 & City Bank Ltd. & $59845.2+10891.2 \mathrm{x}$ & .97 \\
\hline 3 & Eastern Bank Ltd. & $50563.2+10574 \mathrm{x}$ & .97 \\
\hline 4 & IFIC Bank Ltd. & $48755.2+10498 \mathrm{x}$ & .96 \\
\hline 5 & Mercantile Bank Ltd. & $64969.2+15184.7 \mathrm{x}$ & .94 \\
\hline
\end{tabular}

Sources: Annual reports of Brac Bank, City Bank, Eastern Bank, IFIC Bank and Mercantile Bank (2007-2011).

\subsection{Loan and Advances:}

From the table 7 below, it can be found that the loan and advances of every private commercial bank have grown from the previous year. In 2007, Brac Bank has provided the highest loans and advances and the amount is 32461 million whereas City Bank has provided the lowest loan and advances and its amount is 26788 million.

Table 7: Total Loans \& Advances of Selected Private Commercial Banks (in millions)

\begin{tabular}{|c|c|c|c|c|c|c|}
\hline SL & Name of Banks & \multicolumn{5}{|c|}{ Loan and Advances } \\
\hline & & 2007 & 2008 & 2009 & 2010 & 2011 \\
\hline 1 & Brac Bank Ltd. & 32461 & 52677 & 64151 & 82461 & 90822 \\
\hline & Growth & & $62.28 \%$ & $21.78 \%$ & $28.54 \%$ & $10.14 \%$ \\
\hline 2 & City Bank Ltd. & 26788 & 34421 & 43486 & 60327 & 76807 \\
\hline & Growth & & $28.49 \%$ & $26.34 \%$ & $38.73 \%$ & $27.32 \%$ \\
\hline 3 & Eastern Bank Ltd. & 30962 & 39662 & 47668 & 58607 & 81774 \\
\hline & Growth & & $28.10 \%$ & $18.32 \%$ & $14.71 \%$ & $33.87 \%$ \\
\hline 4 & IFIC Bank Ltd. & 28361 & 33018 & 37794 & 47563 & 63558 \\
\hline & Growth & & $16.42 \%$ & $14.46 \%$ & $25.85 \%$ & $33.63 \%$ \\
\hline
\end{tabular}


International Journal of Managing Value and Supply Chains (IJMVSC) Vol. 5, No. 4, December 2014

\begin{tabular}{|c|c|c|c|c|c|c|}
\hline 5 & $\begin{array}{c}\text { Mercantile Bank } \\
\text { Ltd. }\end{array}$ & 31877 & 43419 & 48296 & 66378 & 79999 \\
\hline & Growth & & $36.21 \%$ & $11.23 \%$ & $37.44 \%$ & $20.52 \%$ \\
\hline
\end{tabular}

Sources: Annual reports of Brac Bank, City Bank, Eastern Bank, IFIC Bank and Mercantile Bank (2007-2011).

The provision of loan and advances has dramatically increased in case of Brac Bank in 2008. The percentage of growing rate is $62.28 \%$. Other banks have increased their loans and advances at a normal rate from 2007 to 2008. Again in 2011, the highest loans and advances provided by all the banks belongs to Brac Bank amounted to 90822 million. The lowest amount of loans and advances in 2011 is provided by IFIC Bank and its amount is 63558 million.

Table 8: Trend equation and $r^{2}$ of Loan and Advances

\begin{tabular}{|c|c|c|c|}
\hline SL & Bank & $\mathrm{Y}_{\mathrm{c}}=\mathrm{a}+\mathrm{bx}$ & $\mathrm{r}^{2}$ \\
\hline 1 & Brac Bank Ltd. & $64514.4+14650.6 \mathrm{x}$ & .98 \\
\hline 2 & City Bank Ltd. & $48365.8+12594.4 \mathrm{x}$ & .97 \\
\hline 3 & Eastern Bank Ltd. & $51734.6+12056.9 \mathrm{x}$ & .94 \\
\hline 4 & IFIC Bank Ltd. & $42058.8+8493.9 \mathrm{x}$ & .93 \\
\hline 5 & Mercantile Bank Ltd. & $53993.8+11920.3 \mathrm{x}$ & .97 \\
\hline
\end{tabular}

Sources: Annual reports of Brac Bank, City Bank, Eastern Bank, IFIC Bank and Mercantile Bank (207-2011).

Table 8 indicates positive value of trend equation and Brac Bank dictates that this bank belongs to the highest value for trend equation. Brac Bank also shows that this has the highest value foe square of correlation coefficient. But every selected bank shows the value of square correlation coefficient more than .90 .

\subsection{Classified Loan:}

Table 9 shows the classified loan managed by the selected private commercial banks. It is seen from the table that Eastern Bank is able to manage the credit more efficiently than any other bank because recovery is better for this bank. In case of other banks, the recovery rate follows an unusual rate. That is, recovery rate varies to a great extent from year to year.

Table 9: Classified Loan of Selected Private Commercial Banks (in millions)

\begin{tabular}{|c|c|c|c|c|c|c|}
\hline SL & Name of Banks & \multicolumn{5}{|c|}{ Classified Loan } \\
\hline & & 2007 & 2008 & 2009 & 2010 & 2011 \\
\hline 1 & Brac Bank Ltd. & 1445 & 2473 & 3878 & 4930 & 4240 \\
\hline & Growth & & $71.14 \%$ & $56.81 \%$ & $27.13 \%$ & $6.29 \%$ \\
\hline
\end{tabular}


International Journal of Managing Value and Supply Chains (IJMVSC) Vol. 5, No. 4, December 2014

\begin{tabular}{|c|c|c|c|c|c|c|}
\hline 2 & City Bank Ltd. & 463 & 780 & 708 & 970 & 1101 \\
\hline & Growth & & $80.12 \%$ & $-18.62 \%$ & $37.01 \%$ & $13.51 \%$ \\
\hline 3 & Eastern Bank Ltd. & 1334 & 1309 & 1172 & 1169 & 1561 \\
\hline & Growth & & $-1.87 \%$ & $-10.47 \%$ & $-0.26 \%$ & $33.53 \%$ \\
\hline 4 & IFIC Bank Ltd. & 671 & 1341 & 1744 & 2179 & 2768 \\
\hline 5 & Growth & & $99.85 \%$ & $30.05 \%$ & $24.94 \%$ & $27.03 \%$ \\
\hline & Mercantile Bank & 564 & 578 & 630 & 618 & 712 \\
\hline & Growth & & $2.48 \%$ & $9.00 \%$ & $-1.90 \%$ & $15.21 \%$ \\
\hline
\end{tabular}

Sources: Annual reports of Brac Bank, City Bank, Eastern Bank, IFIC Bank and Mercantile Bank (2007-2011)

Form table 10, it can be said that the trend equation of classified loan is positive. The square of correlation coefficient is the least for Eastern Bank which means that this bank has better recovery system than any other bank.

Table 10: Trend equation and $r^{2}$ of Classified Loan

\begin{tabular}{|c|c|c|c|}
\hline SL & Bank & $\mathrm{Y}_{\mathrm{c}}=\mathrm{a}+\mathrm{bx}$ & $\mathrm{r}^{2}$ \\
\hline 1 & Brac Bank Ltd. & $3593.2+1004.7 \mathrm{x}$ & .97 \\
\hline 2 & City Bank Ltd. & $804.4+146.6 \mathrm{x}$ & .89 \\
\hline 3 & Eastern Bank Ltd. & $1309+31.4 \mathrm{x}$ & .10 \\
\hline 4 & IFIC Bank Ltd. & $1740.6+503.2 \mathrm{x}$ & .99 \\
\hline 5 & Mercantile Bank Ltd. & $620.4+33.6 \mathrm{x}$ & .84 \\
\hline
\end{tabular}

Sources: Annual reports of Brac Bank, City Bank, Eastern Bank, IFIC Bank and Mercantile Bank (2007-2011).

\subsection{Net Income after Tax:}

Net income of selected commercial banks is shown in Table 11. From the table we see that in 2007 the highest net income is for IFIC Bank and the lowest amount is for City Bank and their amount is respectively 964 million and 343 million. 
International Journal of Managing Value and Supply Chains (IJMVSC) Vol. 5, No. 4, December 2014

Table 11: Net Income of Selected Private Commercial Banks (in millions)

\begin{tabular}{|c|c|c|c|c|c|c|}
\hline SL & Name of Banks & \multicolumn{5}{|c|}{ Net Income after Tax } \\
\hline & & 2007 & 2008 & 2009 & 2010 & 2011 \\
\hline 1 & Brac Bank Ltd. & 618 & 973 & 1304 & 1670 & 1702 \\
\hline & Growth & & $57.44 \%$ & $34.02 \%$ & $28.07 \%$ & $1.92 \%$ \\
\hline 2 & City Bank Ltd. & 343 & 398 & 819 & 1849 & 2083 \\
\hline & Growth & & $3.92 \%$ & $5.28 \%$ & $341.29 \%$ & $12.66 \%$ \\
\hline 3 & $\begin{array}{c}\text { Eastern Bank } \\
\text { Ltd. }\end{array}$ & 419 & 798 & 1455 & 2425 & 2521 \\
\hline 4 & $\begin{array}{c}\text { Growth } \\
\text { IFIC Bank Ltd. }\end{array}$ & 964 & 657 & 899 & 1647 & 715 \\
\hline & $\begin{array}{c}\text { Growth } \\
\text { Lercantile Bank }\end{array}$ & 540 & 616 & 808 & 1425 & 1734 \\
\hline & Lrowth & & $14.07 \%$ & $31.17 \%$ & $76.36 \%$ & $21.68 \%$ \\
\hline
\end{tabular}

Sources: Annual reports of Brac Bank, City Bank, Eastern Bank, IFIC Bank and Mercantile Bank (2007-2011).

In 2008, IFIC Bank has failed to sustain the net income. That is, the net income has been decreased by $31.85 \%$. But other banks are showing an increasing rate from 2007 to 2008. In 2011, Eastern Bank belongs to the highest net income and IFIC Bank belongs to the lowest net income. Their amount is respectively 2521 million and 715 million.

Table 12: Trend equation and $\mathrm{r}^{2}$ of Net income

\begin{tabular}{|c|c|c|c|}
\hline SL & Bank & $\mathrm{Y}_{\mathrm{c}}=\mathrm{a}+\mathrm{bx}$ & $\mathrm{r}^{2}$ \\
\hline 1 & Brac Bank Ltd. & $1253.4+286.5 \mathrm{x}$ & .96 \\
\hline 2 & City Bank Ltd. & $1098.4+493.1 \mathrm{x}$ & .91 \\
\hline 3 & Eastern Bank Ltd. & $1523.6+583.1 \mathrm{x}$ & .96 \\
\hline 4 & IFIC Bank Ltd. & $976.4+49.2 \mathrm{x}$ & .04 \\
\hline 5 & Mercantile Bank Ltd. & $1024.60+319.7 \mathrm{x}$ & .92 \\
\hline
\end{tabular}

Sources: Annual reports of Brac Bank, City Bank, Eastern Bank, IFIC Bank and Mercantile Bank (207-2011). 
It is shown from table 12 that the trend equation value of net income is highly positive. IFIC Bank holds comparatively little net income in comparison with other banks. Brac Bank, City Bank, Eastern Bank and Mercantile Bank have high net income. Again, among all the banks Eastern bank shows the highest trend value for net income and also its square of correlation coefficient is higher. It indicates that Eastern Bank provides a strong evidence of high net income.

\subsection{Earnings per Share:}

Table 13 shows earning per share of selected commercial banks of Bangladesh. Though earning per share for Eastern Bank is lower than any other selected bank but only this bank is showing positive trend. That is, every year net income has increased more than the previous year. For any other bank, the percentage of growing rate fluctuates. For example, in case of IFIC Bank net income has decreased for 2008, 2009 and 2011 but increased in 2010. In 2011, Brac Bank has the highest earning per share and Eastern Bank has the lowest earning per share and their amount is respectively is 66.49 and $5.57 \mathrm{tk}$.

Table 13: Earning Per Share of Selected Private Commercial Banks

\begin{tabular}{|c|c|c|c|c|c|c|}
\hline SL & Name of Banks & \multicolumn{5}{|c|}{ Earnings Per Share } \\
\hline & & 2007 & 2008 & 2009 & 2010 & 2011 \\
\hline 1 & Brac Bank Ltd. & 32.3 & 62.3 & 48.24 & 68.17 & 66.49 \\
\hline & Growth & & $47.28 \%$ & - & $41.31 \%$ & $-2.46 \%$ \\
\hline 2 & City Bank Ltd. & 25.14 & 29.14 & 27.35 & 59.35 & 64.7 \\
\hline 3 & Growth & & $15.91 \%$ & $-6.18 \%$ & $117.08 \%$ & $9.01 \%$ \\
\hline 4 & Eastern Bank Ltd. & 3.02 & 3.45 & 5 & 5.36 & 5.57 \\
\hline & IFIC Bank Ltd. & 71.93 & 49 & 41.27 & 75.56 & 32.76 \\
\hline 5 & $\begin{array}{c}\text { Mrowth } \\
\text { Lercantile Bank }\end{array}$ & 36.06 & 34.24 & 37.41 & 41.04 & 49.91 \\
\hline & Growth & & $-5.05 \%$ & $-8.27 \%$ & $30.66 \%$ & $21.61 \%$ \\
\hline
\end{tabular}

Sources: Annual reports of Brac Bank, City Bank, Eastern Bank, IFIC Bank and Mercantile Bank (2007-2011).

It can be drawn from table 14 that every bank is able to earn a positive amount for every share. From the trend value shown on the table, Eastern Bank earns less than any other selected bank. The square of correlation coefficient $\left(\mathrm{r}^{2}\right)$ is more than .5 for every selected bank except IFIC 
Bank. City Bank is showing the highest value for $\left(r^{2}\right)$ i.e. .81 . That is, the goodness of fit is better for City Bank than any other selected bank in our study.

Table 14: Trend equation and $r^{2}$ of Earning Per Share

\begin{tabular}{|c|c|c|c|}
\hline SL & Bank & $\mathrm{Y}_{\mathrm{c}}=\mathrm{a}+\mathrm{bx}$ & $\mathrm{r}^{2}$ \\
\hline 1 & Brac Bank Ltd. & $57.5+5.43 \mathrm{x}$ & .55 \\
\hline 2 & City Bank Ltd. & $41.14+10.93 \mathrm{x}$ & .81 \\
\hline 3 & Eastern Bank Ltd. & $4.37+.59 \mathrm{x}$ & .78 \\
\hline 4 & IFIC Bank Ltd. & $54.1+5.18 \mathrm{x}$ & .19 \\
\hline 5 & Mercantile Bank Ltd. & $39.73+3.45 \mathrm{x}$ & .77 \\
\hline
\end{tabular}

Sources: Annual reports of Brac Bank, City Bank, Eastern Bank, IFIC Bank and Mercantile Bank (2007-2011).

\section{FINDINGS:}

From this study, it is found that the private commercial banks are performing better during the working year than the previous years. That is, every year the banks are showing progress in itsperformance.The study also shows that every private commercial bank is employing some more people every year. That is, because every year the number of branches is increasing due to maintaining the increasing activities of the new branches of the banks. Almost every year the selected private commercial banks have increased their branches. This study has shown that IFIC bank holds the highest number of branches in 2011 and the number of branches is 99.As the services are spreading throughout the country day by day, people from every section have started to take the services provided by these private commercial banks. As the services have grown up, it has contributed a lot to net income. Net income of the selected private commercial banks has shown a growing trend in this study from 2007 to 2011. As banks serve as a secured place to keep money, the deposits collected from the clients come to private banks more than any other banks. Throughout the years (2007-2011) of this analysis, it is seen that the deposits have increased one year after another. This has been possible for providing the better services by the private commercial banks. Performance can also be evaluated by means of Earning per Share (EPS) which has been shown very high for every commercial bank except IFIC Bank. It dictates that almost every bank is earning as per required. Loan recovery rate dictates how much efficient the banks are to manage the amount of loan they are providing to their clients. The analysis indicates that Eastern Bank is very efficient to manage their credit.

To determine different activities of the private commercial banks, another equation method has been used and that is trend equation. The trend equations which have been tested show different results for individual activity. Among all the trend values, the values of branches, employees and deposits show highly positive result i.e. more than $70 \%$.

After measuring trend equation for different variables, square of correlation coefficient $\left(r^{2}\right)$ has been tested. From the analysis of $\left(r^{2}\right)$, it has been noticed that the square of correlation coefficient is more than 0.5 in case of branches deposits, net income and deposit. So, it reveals that there is a very good prospect of private commercial banks in Bangladesh.

In the analysis, it hasbeen found that the number of branches of every bank has increased every year except one year in case of City Bank. From 2007 to 2008 there is no increase of branches 
for City Bank. But from 2008 to 2009, City Bank has begun to show a growing trend. It has been seen that all the banks have increased their branches due to performing increasing activities and increasing income. Accumulating deposit is very essential for any bank and every bank desires to increase its deposit. The analysis has shown that deposit is on the increase every year more than the previous year. But deposit collected by BRAC Bank and Mercantile Bank is higher than that of City Bank, Eastern Bank and IFIC Bank. The banks which are lagging behind to accumulate deposit should put more emphasis on deposit collection. Loan and advances are considered as a means of earning. So every bank should concentrate on it. This analysis reflects that BRAC Bank has done well in allocating loan and advances. Whatever the case is, every bank wants to sustain consistent growth rate because, it helps the bank to make a budget or plan for next year. In this analysis, Mercantile Bank has superseded every other bank in case of consistent growth.

\section{CONCLUSION:}

The banking sector is playing a major role to materialize most of the transactions happening throughout the world. Therefore, this sector has to ensure better services from their part and prove them to be profitable handling all sorts of internal and external pressures skilfully.Financial performance appraisal helps both banks and its stakeholders to assess the outcomes of the bank's policies and operations in monetary terms. Bangladesh has a bank dominated financial market. Therefore for her economic sustainability, the contribution of bank is inevitable. Any disturbance to her banking sector can severely paralyze the whole economy. Moreover, the number of banks in Bangladesh is very rapidly progressing. These banks are embracing the economy and the lives of Bangladeshi citizens. Therefore, it is very important to monitor the performance and contribution of these banks from time to time. This study is just an effort to do that in a smaller prospect. However, in this study, five private commercial banks that are among the top performers have been selected for analysis. So, this study hopes that the concerned authorities of the selected banks as well as the policy makers and other stakeholders will get a precise overview of the performance trend of these banks. Other banks will also get competitive information and overall all the concerned parties will be able to necessary steps as per their requirements.

\section{REFERENCES:}

1. S. Teker, D. Teker and O. Kent. "Measuring Commercial Banks' Performances in Turkey: A Proposed Model,” Journal of Applied Finance \& Banking, vol. 1, pp. 97-112, 2011.

2. J. Stankeviciene and E. Mencaite. "The evaluation of bank performance using a multicriteria decision making model: a case study on Lithuanian commercial banks," Technological and Economic Development of Economy, vol. 18, pp. 189-205, 2012.

3. P.K. Aspal and N. Malhotra. "Performance Appraisal of Indian Public Sector Banks," World Journal of Social Sciences, vol. 3, pp. 71 - 88, 2013.

4. Bangladesh Bank. "Financial Systems: Banks and Financial Institutions." Internet: http://www.bb.org.bd/fnansys/bankfi.php [Aug. 21, 2012].

5. R.K. Uppal. "Stability in Bank Income through Free-Based Activities," Journal of Information Management and Business Review, vol. 1, pp. 1-8, 2010.

6. S.H. Siddique and A.F.M.M. Islam. "Banking Sector in Bangladesh: Its Contribution and Performance," Journal of Business Research, Jahangirnagar University, vol. 3, pp. 16-33, 2001.

7. A, Chowdhury. "Politics, Society and Financial Sector Reform in Bangladesh," International Journal of Social Economies, vol. 4, pp. 963 - 988, 2002.

8. A.A. Almazari. "Financial Performance Evaluation of Some Selected Jordanian Commercial Banks,” International Research Journal of Finance and Economics, vol. 68, pp. 50-63, 2011. 
International Journal of Managing Value and Supply Chains (IJMVSC) Vol. 5, No. 4, December 2014

9. E.F. Brigham and J.F. Houston. "Analysis of financial statement" in Fundamentals of Financial Management, 10th ed., United States: South-Western Thomson Learning, 2004, pp. 74-112.

10. M.K. Hossain and R.H. Bhuiyan. "Performance Dynamics of Nationalized Commercial Banks in Bangladesh," Journal of Business Studies, University of Dhaka, vol. 11, pp. 22-65, 1990.

11. A. Shleifer. "State census private ownership," Journal of economic perspective, vol. 12, pp. 133150, 1998.

12. H.A. Chowdhury and M.S. Islam. "Interest Rate Sensitivity of Loans and Advances: A Comparative Study between Nationalized Commercial Banks and specialized Banks," ASA University Review, vol. 1, pp. 86-97, 2007.

13. P.R. Bhatt and R. Ghosh. "Profitability of Commercial Banks in India," Indian Journal of Economics, vol. 3, pp. 14-27, 1992.

14. N. Jahangir, S. Shill and M.A.J. Haque. "Examination of Profitability in the Context of Bangladesh Banking Industry,” ABAC Journal, vol. 27, pp. 36-46, 2007.

15. I.M. Pandey. "Financial statement analysis", Financial Management, 9th ed., New Delhi, India: Vikas Publishing House, 2004.

16. N. Alam and B. Jahan. "Default culture in banking sector in Bangladesh." Bank Parikrama, vol. 24, pp. 261-273, 1999.

17. M. Al-Shammari and M. Salimi. "Modeling the operating efficiency of banks, A parametric methodology," Journal of Logistic Information Management, vol. 11, pp. 27-41, 1998

18. J.C.V. Horne and J.M. Wachowicz. "Financial Statement Analysis," in Fundamentals of financial management, 11th ed., Delhi, India: Pearson Education Asia, 2005, pp. 125-168.

19. N.K. Avkiran. "Models of retail performance for bank branches: predicting the level of key business drivers," International Journal of Bank Marketing, vol. 15, pp. 1-23, 1997.

20. M.R. Swamy and S.V. Vashudevan. A Text Book of Banking, New Delhi: S. Chand \& Company, 1985.

21. A. Alkhatib and M. Harsheh. "Financial Performance of Palestinian Commercial Banks," International Journal of Business and Social Science, vol. 3, pp. 175- 184, 2012.

22. M.U.D. Sangmi and T. Nazir. "Analyzing Financial Performance of Commercial Banks in India: Application of CAMEL Model," Pakistan Journal of Commerce and Social Sciences, vol. 4, pp. 40-55, 2010.

23. M.K. Roy and S.H. Khan. "Study on Private Commercial Banks in Bangladesh," ASA University Review, vol. 7, pp. 63-80, 2013.

24. R.A. Karim and T. Alam. "An Evaluation of Financial Performance of Private Commercial Banks in Bangladesh: Ratio Analysis," Journal of Business Studies Quarterly, vol. 5, pp. 65-77, 2013.

25. K. Kosmidou and C. Zopounidis. "Measurement of Bank Performance in Greece," South-Eastern Europe Journal of Economics, vol. 1, pp. 79-95, 2008.

26. S. Chantapong. "Comparative Study of Domestic and Foreign Bank Performance in Thailand: The Regression Analysis,” Economic Change and Restructuring, vol. 38, pp. 63-83, 2005.

27. B.J. Hirtle and K.J. Stiroh. "The return to retail and the performance of US banks," Journal of Banking \& Finance, vol. 31, pp. 1101-1133, 2007.

28. C.T. Ho and D.S. Zhu. "Performance measurement of Taiwan's commercial banks," International Journal of Productivity and Performance Management, vol. 53, pp. 425 - 434, 2004.

29. M. Kumbirai and R. Webb. "A financial Ratio Analysis of Commercial Bank Performance in South Africa," African Review of Economics and Finance, vol. 2, pp. 30-53, 2010.

30. N.K. Malhotra and S. Dash. Marketing Research, 6th ed., New Delhi, India: Dorling Kindersley, 2011.

31. S.P. Gupta and M.P. Gupta. Business Statistics, New edition, New Delhi: Sultan Chand and Sons, 2003. 